\title{
Applications of Nanotechnology in Sensor-Based Detection of Foodborne Pathogens
}

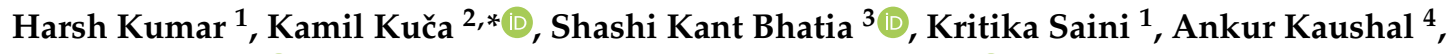 \\ Rachna Verma ${ }^{5}$ D, Tek Chand Bhalla ${ }^{6}$ and Dinesh Kumar $1, * \mathbb{D}$ \\ 1 School of Bioengineering \& Food Technology, Shoolini University of Biotechnology and Management \\ Sciences, Solan 173229, H.P., India; microharshs@gmail.com (H.K.); sainikritika@gmail.com (K.S.) \\ 2 Center for Basic and Applied Research, Faculty of Informatics and Management, University of Hradec \\ Kralove, Hradec Kralove 50003, Czech Republic \\ 3 Department of Biological Engineering, College of Engineering, Konkuk University, Seoul 143-701, Korea; \\ shashikonkukuni@konkuk.ac.kr \\ 4 Centre of Nanotechnology, Amity University, Manesar, Gurugram, Haryana 122413, India; \\ ankur.biotech85@gmail.com \\ 5 School of Biological and Environmental Sciences, Shoolini University of Biotechnology and Management \\ Sciences, Solan 173229, H.P., India; rachnaverma@shooliniuniversity.com \\ 6 Department of Biotechnology, Himachal Pradesh University, Summer Hill, Shimla 171005, H.P., India; \\ bhallatc@rediffmail.com \\ * Correspondence: kamil.kuca@uhk.cz (K.K.); dineshkumar@shooliniuniversity.com (D.K.)
}

Received: 11 March 2020; Accepted: 30 March 2020; Published: 1 April 2020

check for updates

\begin{abstract}
The intake of microbial-contaminated food poses severe health issues due to the outbreaks of stern food-borne diseases. Therefore, there is a need for precise detection and identification of pathogenic microbes and toxins in food to prevent these concerns. Thus, understanding the concept of biosensing has enabled researchers to develop nanobiosensors with different nanomaterials and composites to improve the sensitivity as well as the specificity of pathogen detection. The application of nanomaterials has enabled researchers to use advanced technologies in biosensors for the transfer of signals to enhance their efficiency and sensitivity. Nanomaterials like carbon nanotubes, magnetic and gold, dendrimers, graphene nanomaterials and quantum dots are predominantly used for developing biosensors with improved specificity and sensitivity of detection due to their exclusive chemical, magnetic, mechanical, optical and physical properties. All nanoparticles and new composites used in biosensors need to be classified and categorized for their enhanced performance, quick detection, and unobtrusive and effective use in foodborne analysis. Hence, this review intends to summarize the different sensing methods used in foodborne pathogen detection, their design, working principle and advances in sensing systems.
\end{abstract}

Keywords: nanotechnology; nanomaterials; safety; sensor; foodborne pathogens

\section{Introduction}

Nanotechnology is the science to understand the matter at a nanoscale dimension, generally ranging between 1 and $100 \mathrm{~nm}$. This technology involves the fabrication, manipulation, study of technique, material, modes and use of nano-devices in various applications. Nowadays, nanotechnology is extensively used in developing biosensors using different types of nanocomposite [1-3]. The different nanomaterials used in nanotechnology display unique features including chemical, physical and surface effects because of their dimensions and tolerances to sizes less than 100 nanometers. 
Every year globally, contaminated food is responsible for 420000 deaths and 600 million cases of food-borne infection. According to $\mathrm{WHO}$, approximately $30 \%$ of death occurs among children ( $\leq 5$ years) due to foodborne disease [4]. The established microbial culture methods may help in the detection of a single specific bacterium, but this procedure takes a few days for results, and in many instances these methods do not produce considerable data. By using nanotechnology-based methods, the pathogenic bacteria present in complex food products can be detected with high sensitivity and specificity as compared to the conventional methods [5-7]. A biosensor is a device in which a biological element (i.e., an antibody, receptor, nucleic acid, or other biorecognition element) interacts with an analyte and the response thus generated is transformed into an electrical signal by a transducer. The response of biosensors is highly specific, quick, free from interference, and has low limits for detection, but still the non-targeted microorganisms can interfere with the operations of biosensors.

The development of many signal transduction technologies using nanomaterials in biosensor is transforming the field of biological and chemical analysis to empower in vivo studies. In microbial detection, highly fascinating and promising outcomes have been produced in research using nanotechnology. The characteristics of nanomaterials with high surface permeability, higher surface to volume ratio, reactivity, and high penetrability allow less material and substrate usage and as compared to large size materials, they work more efficiently in physical and chemical reactions [8]. A high advantage of establishing a small automated system was worked out for the use in field with rapid and cost-effective microbial detection, and sensitive stick tests were developed by using gold nanoparticles with high specificities for the same [9-11]. This review highlights the effectiveness of nanomaterials for developing biosensors, especially for detecting the microbial pathogens present in contaminated food. The first section of this review describes the various properties of the nanomaterials used for sensing applications, and the safety issues and guidelines issued by various organizations for use at workplace or in laboratories. The other section discusses the utilization of nanomaterials and present status of sensors used for the detection of foodborne pathogens in various food matrixes.

\section{Criteria for Selection of Nanomaterials for use in Biosensors}

Nanosensors are generally used for the measurement of biological response output quantity as well as for conversion of biological response into output signals for further interpretation and analysis. The selection of nanomaterial used in various biosensing applications is dependent on its properties (Table 1). 
Table 1. Properties, and synthesis of different types of nanomaterials used in sensors fabrication and other applications.

\begin{tabular}{|c|c|c|c|c|}
\hline Nanomaterials & Physical Properties & Synthesis & Applications & Ref \\
\hline Gold & $\begin{array}{c}\text { Redox activity } \\
\text { Surface-enhanced Raman scattering (SERS) } \\
\text { Surface Plasmon resonance (SPR) } \\
\text { Fluorescence quenching }\end{array}$ & Solution-based approaches & $\begin{array}{l}\text { Sensing: electronic devices and electrochemical sensing } \\
\text { Therapeutics: drugs delivery } \\
\text { Imaging: cell imaging, target tumor specific antigens }\end{array}$ & [12] \\
\hline Carbon Nanostructures & $\begin{array}{c}\text { Equilibrium structure } \\
\text { Lattice constant viz lattice parameter, density, } \\
\text { interlayer spacing } \\
\text { Optical properties viz fundamental gap } \\
\text { Electrical transport } \\
\text { Thermal transport } \\
\text { Elastic behaviour }\end{array}$ & $\begin{array}{l}\text { Chemical vapour deposition technique } \\
\text { Laser-ablation technique } \\
\text { Carbon arc-discharge technique }\end{array}$ & $\begin{array}{l}\text { Biomedical applications: artificial implants, tissue engineering, } \\
\text { cancer cell identification and drugs and genes delivery } \\
\text { Electrochemical devices: supercapacitors and electromechanical } \\
\text { actuators used in robots and hybrid electric vehicles } \\
\text { Hydrogen storage: fuel cells that powers electric vehicles and } \\
\text { laptop computers } \\
\text { Field emission devices: lamps, gas discharge tubes, microwave } \\
\text { generators } \\
\text { Sensors and Probes }\end{array}$ & {$[13,14]$} \\
\hline Magnetic Nanoparticles & $\begin{array}{l}\text { Magnetic effect due to spinning electric- charged } \\
\text { particle } \\
\text { Critical size depends on magnetic saturation, } \\
\text { strength of crystal, exchange forces, surface energy, } \\
\text { and shape of the particles } \\
\text { Zero coercivity }\end{array}$ & $\begin{array}{l}\text { Co-precipitation } \\
\text { Microemulsion } \\
\text { Thermal decomposition } \\
\text { Solvothermal } \\
\text { Sonochemic } \\
\text { Microwave assisted } \\
\text { Chemical vapour deposition } \\
\text { Combustion synthesis } \\
\text { Carbon arc } \\
\text { Laser pyrolysis }\end{array}$ & $\begin{array}{l}\text { Industrial applications: used as synthetic pigments in ceramics, } \\
\text { paints and porcelain } \\
\text { Biomedical applications: used in vivo to destroy the pathological } \\
\text { cells by hyperthermia, drugs delivery, NMR imaging, } \\
\text { bioseparation of specific biological entities from their native } \\
\text { environment } \\
\text { Environmental applications: removal of organic and inorganic } \\
\text { pollutants }\end{array}$ & [15] \\
\hline Silicon Nanomaterials & $\begin{array}{l}\text { Optical properties viz bright emission, } \\
\text { photostability, size dependent and wavelength } \\
\text { tuneable luminescence and long fluorescence } \\
\text { Electronic properties viz quantum confinement, } \\
\text { type of dopant, composition of material, surface } \\
\text { functionalization and post treatment }\end{array}$ & $\begin{array}{l}\text { Pulsed laser ablation } \\
\text { Heating degradation } \\
\text { Ball milling } \\
\text { Chemical synthesis } \\
\text { Electrochemical etching }\end{array}$ & $\begin{array}{l}\text { Light- emitting applications: multicolour silicon-based light } \\
\text { emission diodes } \\
\text { Energy and Electronic fields: lithium battery, solar cell battery, } \\
\text { Microwave assisted } \\
\text { filed-effect transistor } \\
\text { Photocatalysts }\end{array}$ & [16] \\
\hline Graphene oxide & $\begin{array}{l}\text { Mechanical properties to enhance the strength } \\
\text { Electrical properties include high electron mobility } \\
\text { and electrical conductivity } \\
\text { Thermal properties }\end{array}$ & $\begin{array}{l}\text { Bottom-up approach } \\
\text { Top-down approach }\end{array}$ & $\begin{array}{c}\text { Membranes and Coatings: gas transport, water treatment } \\
\text { Stimuli-responsive materials: humidity actuation, thermal/light } \\
\text { responsive actuation, electrochemical actuation, multi-stimuli } \\
\text { actuation } \\
\text { Corrosion resistance } \\
\text { Energy storage: lithium ions batteries, supercapacitors }\end{array}$ & [17] \\
\hline Dendrimers & $\begin{array}{l}\text { Low viscosity } \\
\text { High solubility and miscibility due to many chain } \\
\text { ends } \\
\text { High surface areas in relation to volume } \\
\text { Encapsulate guest molecule in the macromolecular } \\
\text { interior due to their globular shape }\end{array}$ & $\begin{array}{l}\text { Divergent method } \\
\text { Convergent method }\end{array}$ & $\begin{array}{l}\text { Biomedical field: drugs and genes delivery, photodynamic } \\
\text { therapy, enhancing drug solubility } \\
\text { Water purification } \\
\text { Analytical devices }\end{array}$ & {$[18,19]$} \\
\hline Conducting polymers & $\begin{array}{l}\text { High conductivity viz. reversible redox } \\
\text { Nonlinear optical properties } \\
\text { Electric properties } \\
\text { Microwave absorbing properties } \\
\text { Wettability }\end{array}$ & $\begin{array}{l}\text { Chemical method } \\
\text { Electrochemical method } \\
\text { Photochemical method } \\
\text { Concentrated emulsion method } \\
\text { Inclusion method } \\
\text { Plasma polymerization } \\
\text { Pyrolysis method }\end{array}$ & $\begin{array}{l}\text { Electronic devices: light emitting diodes, solar cells } \\
\text { Electromagnetic shielding materials } \\
\text { Microwave absorbing materials } \\
\text { Rechargeable batteries } \\
\text { Sensors }\end{array}$ & [20] \\
\hline
\end{tabular}


Nanomaterial-based sensors are highly sensitive and specific in their nature as compared to the traditional material-based sensors. Some common nanomaterials used in sensor technology are shown in Figure 1.

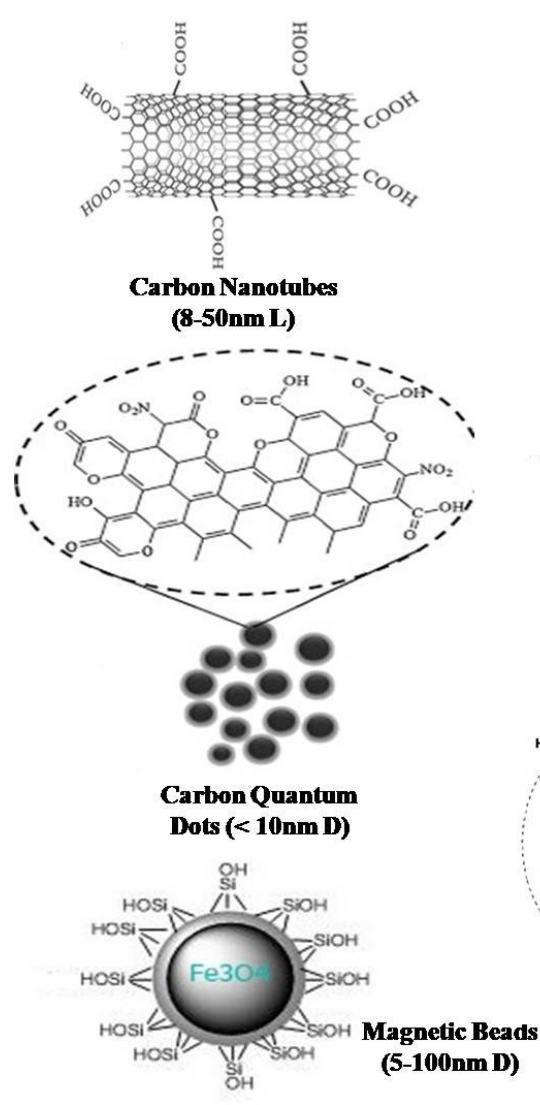

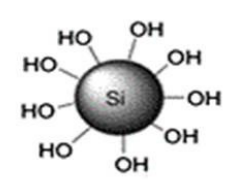

Silicon Nanoparticles

(3-10nm D)
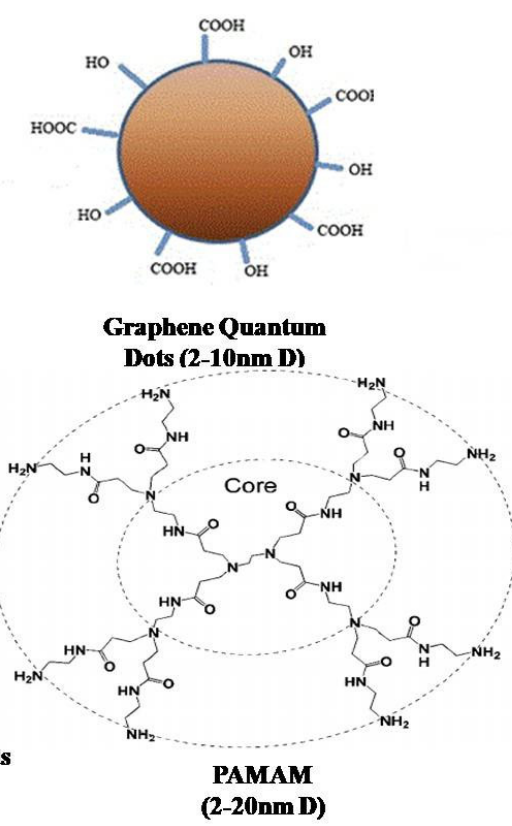
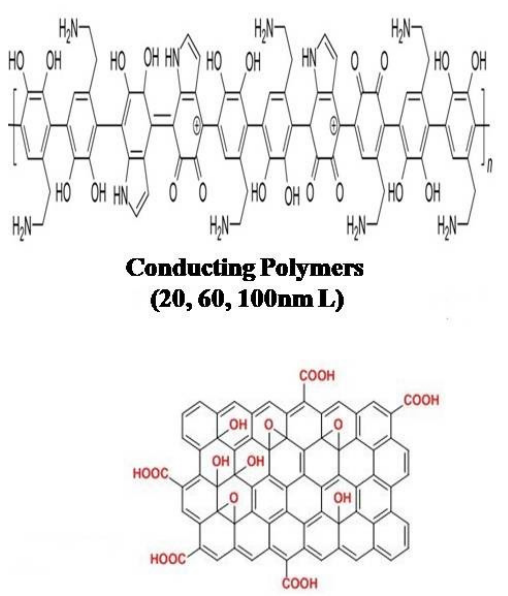

Graphene Oxide (1.18-10.5um L)

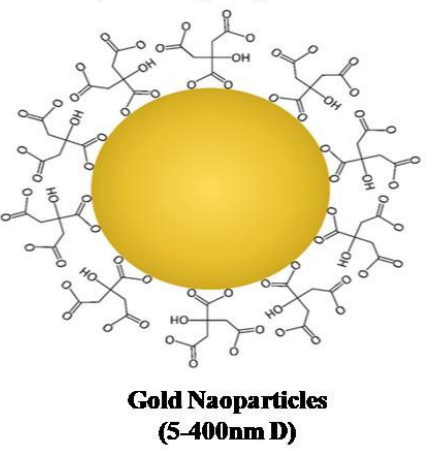

Figure 1. Commonly used nanomaterials in various kind of sensors fabrication with their sizes. L: length; D: Diameter.

The nanosensors are operated at a scale similar to the biological processes to increase the specificity of biological response. One of the important steps of experimental design before addition of a nanomaterial into the sensing application is "Nanofabrication". This step leads to two important actions, i.e., first, the manufacturing and designing of nanoscale adhesive through the use of integrated circuits and second, the use of micromachining processes for the engineering of nanomaterial surfaces. Four basic processes involved in biosensing by nanofabrication are chemical bonding, photolithography, surface etching strategies and thin film etching/growth. With the rise of chronic diseases, e.g., diabetes and cancer, there is a need for awareness among the masses for the early-stage identification of these diseases, as biosensors provide a quick response and high sensitivity at the initial stages. Nanoscale electrodes are produced from the lithography technique, which is one of the basic process of nanofabrication. The use of nanomaterials in biosensing provides better and greater surface area for immobilization with better precision [21]. Glucose biosensors were first developed using this technique by the use of the enzyme glucose oxidase and the detection of analytic materials was improved by the addition of platinum nanoparticles above the sheets of carbon nanotubes. These biosensors enable the recognition of glucose from several sources other than blood. The antigen-antibody complexes formed in the reaction can also be identified by immune-sensors in which thin films are coated above the sensing surface to allow for quick and better recognition of the analytes [22]. 
Nanoelectromechanical systems (NEMS) are other highly sensitive devices with nanoscale functions. This technology, when engineered with nanomaterials, provides novel properties from nanoscale to nanometer level in energy harvesting, sensing display, imaging, portable power generation and also in drug delivery. NEMS, along with micro-electrochemical systems (MEMS) devices, result in better performance with mechanical materials when attached to biological systems and lead to improvement of bio-adhesion features and response to a widespread range of stimuli. This technology enables the demonstration of the biochemical interactions with the help of biomarkers for the rapid diagnosis of new diseases [23]. Flurophores are other important components of biosensors which can absorb and emit light within wavelengths of excitation and emission spectra and make use of total internal reflection. These are commonly used as recognition reagents in flow cytometry in conjugation with the antibody critical angle of reflection.

In nanomaterials, the sensing materials should have sharp and precise scale optical response with the incident light surface plasmon resonance (SPR) [24]. The SPR furnishes the nano-biosensor in a better way and allows the estimation of biological interactions through the detection of the minutest interaction phenomenon. The plasmonic peak of nanoparticles with sizes smaller than $10 \mathrm{~nm}$ can be described in a better way by the modified dielectric function as compared to the other models [25-27]. The safety of the environment and human health is of prime concern and many reports have highlighted the toxicity associated with various nanomaterials (Table 2).

Table 2. Toxicity studies of various used in sensor development under in vitro and in vivo conditions.

\begin{tabular}{|c|c|c|c|}
\hline Nanomaterials & Toxic Effects & Dosage Level & Ref \\
\hline $\begin{array}{l}\text { Multiwalled Carbon } \\
\text { nanotubes }\end{array}$ & $\begin{array}{c}\text { Damage to micronucleus, macronucleus, and membrane } \\
\text { was observed in Stylonychiamytilus } \\
\text { Decrease in maternal, fetal weight and skeletal } \\
\text { malformation in mouse model } \\
\text { Increased abortion rate in mouse model } \\
\text { Increase in C-C motif ligand 20, basic fibroblast growth } \\
\text { factor, and soluble IL-1 receptor II in human subjects }\end{array}$ & $\begin{array}{c}1 \mathrm{mg} / \mathrm{ml} \\
100.8-162.5 \mu \mathrm{g} / \mathrm{mouse} \\
4-20 \mathrm{mg} / \mathrm{kg} \\
45 \mu \mathrm{g} / \mathrm{m}^{3}\end{array}$ & [28-31] \\
\hline $\begin{array}{l}\text { Singlewalled Carbon } \\
\text { nanotubes }\end{array}$ & $\begin{array}{l}\text { Fetal morphological abnormalities in mouse model } \\
\text { Increased resorption rate in mouse model }\end{array}$ & $\begin{array}{l}0.1-30 \mu \mathrm{g} / \mathrm{mouse} \\
10 \mathrm{mg} / \mathrm{kg}\end{array}$ & {$[32,33]$} \\
\hline $\begin{array}{l}\text { Quantum dots } \\
\text { (Cadmium telluride) }\end{array}$ & $\begin{array}{c}\text { Reduction in phagocytic activity and hemocyte viability in } \\
\text { the hemolymph of Elliptio complanata } \\
\text { Reduced survival rate in mouse model }\end{array}$ & $\begin{array}{c}8 \mathrm{mg} / \mathrm{L} \\
20-125 \mu \mathrm{g} / \text { mouse }\end{array}$ & {$[34,35]$} \\
\hline Gold NPs & $\begin{array}{c}\text { Induced decreases in body weight, red blood cells, and } \\
\text { hematocrit in mouse model }\end{array}$ & $550-2200 \mu \mathrm{g} / \mathrm{kg}$ & [36] \\
\hline Polypyrrole & $\begin{array}{l}\text { Cytotoxic for human jurkat cell line, mouse embryonic } \\
\text { fibroblasts and mouse hepatoma cell line (MH-22A) }\end{array}$ & $>19.4 \mu \mathrm{g} / \mathrm{mL}$ & [37] \\
\hline Graphene oxide & $\begin{array}{l}\text { Toxic for the liver, kidney, spleen, lung, intestine, and } \\
\text { brain in rat model }\end{array}$ & $500 \mathrm{mg} / \mathrm{kg}$ & {$[38]$} \\
\hline Magnetite & $\begin{array}{c}\text { Acute inflammation in the liver and tarsal joints, induced } \\
\text { the vaginal secretion IgA, Bcl-2 reactivity in the } \\
\text { hepatocytes in mice model }\end{array}$ & $45 \mathrm{mg} /$ mouse & [39] \\
\hline Dendrimers (PAMAM) & $\begin{array}{l}\text { Increases in lysosomal activity of } \mathrm{HaCaT} \text { cells, an } \\
\text { immortal non-cancerous human keratinocyte cell line }\end{array}$ & $1.5-1.8 \mu \mathrm{M}$ & [40] \\
\hline
\end{tabular}

Many organizations across world have given recommendations regarding the safety of researchers and employees dealing with nanomaterials at the workplace (Table 3). 
Table 3. Guidelines/recommendations to address the safety of nanomaterials used in sensor fabrication.

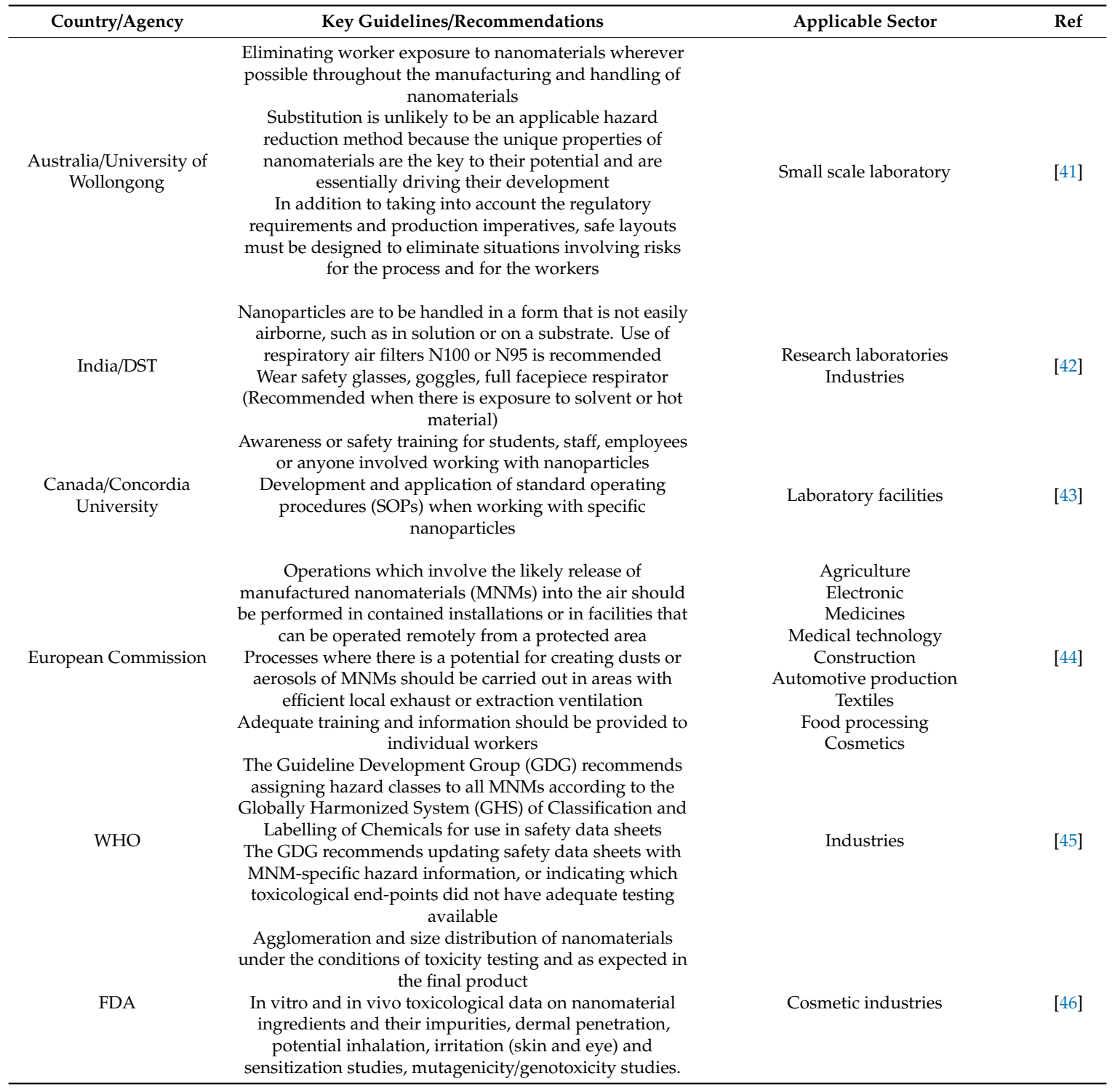

\section{Various Nanomaterials used for Sensor Fabrication with Special Reference to Food Borne Pathogens}

\subsection{Carbon Nanotubes}

In the last decade, carbon nanotubes (CNTs) have emerged as one of the most extensively used nanomaterials in drug delivery and in biomolecular techniques. CNTs are cylindrical hollow tubes containing one or more concentric layers of graphite enclosed by fullerenic hemispheres, referred to as single- to multi-walled CNTs, respectively. They have unique structures, high electrical and mechanical properties, chemical stability, light weight, high thermal conductivity, unique electrocatalytic action, minimal surface fouling and high surface to volume ratio [47].

The key challenge for developing effective biosensors is their specificity, sensitivity and detection time to assess the presence of food-borne pathogens in normal and toxin-supplemented samples. Single-wall surface carbon nanotubes (SWCNTs) were employed in a DNA sensor application for the detection of Salmonella using N-ethyl-N'-(3-dimethylaminopropyl) carbodiimide hydrochloride (3-dimethylaminopropyl) covalently bonded to the nanotubes [48]. For this, an electrode along with ssDNA probe solution (Salmonella specific) was incubated at room temperature for $2 \mathrm{~h}$. The sensor 
showed sensitivity at the target concentration of $1 \times 10^{-9} \mathrm{~mol} / \mathrm{L}$ DNA. Moreover, no fluctuation was noted in the signal via the ssDNA probe on the mismatching of the single nucleotide. An amino-modified aptasensor was developed using indium tin oxide (ITO) deposited on a multi-walled carbon nanotube (MWCNTs) electrode and assessed for the detection of Salmonella enteritidis and Salmonella typhimurium with detection limits of $5.5 \times 10^{1}$ and $6.7 \times 10^{1} \mathrm{cfu} \mathrm{mL}^{-1}$, respectively [49]. Additionally, the sensitivity of an aptasensor was validated via the PCR technique, by detecting the 148bp invA gene, which is also present in S. enteritidis and S. typhimurium. The sensitivity limit of PCR was found to be $10^{2} \mathrm{cfu} \mathrm{mL}^{-1}$ for both the strains of Salmonella.Meanwhile, the sensitivity limit of the aptasensor was found to be $10^{1} \mathrm{cfu}$ $\mathrm{mL}^{-1}$ when assessed on raw chicken samples which were spiked with Salmonella. Hence, this confirms that the ssDNA/MWCNTs/ITO electrode coupled to an aptamer is more effective in comparison to PCR detection approach on the basis of its detection limit. Furthermore, the developed sensor shows no specificity against non-Salmonella bacteria. In 2014, the group of researchers immobilized anti-Escherichia coli antibodies on SWCNT-based joint biosensor developed to detect the E. coli K-12 strain. The developed sensor showed the detection limit of $10^{2} \mathrm{cfu} \mathrm{mL} \mathrm{m}^{-1}$ in less than $5 \mathrm{~min}$. Moreover, minute fluctuation in the electric current was detected, when checked with Staphylococcus aureus, which confirms its specificity and sensitivity to E. coli [50].

\subsection{Gold Nanoparticles}

Gold nanoparticles are frequently used in nanotechnology-based applications. Gold nanoparticle (AuNPs) synthesis in organic or aqueous solvents requires a stabilizing mediator (surfactant) for its stability and can be achieved by chemical binding or by adsorption of the appropriate mediator on the gold NPs. Usually, to avoid the aggregation of loaded NPs, the surfactant need to be loaded and different gold NP properties can be adjusted by choosing separate surfactants [51].

The biological compatibility, exceptional conducting capability, and high surface-to-volume ratio are the few characteristics of AuNPs, which makes it the nanoparticle of interest [52]. The redox activity is an interesting characteristic of gold NPs, which enhances the sensitivity of electrochemical biosensors in the analysis of foodborne pathogens. The use of gold NPs onto electrochemical biosensors in conjugation with ssDNA complementary to the microbial DNA under evaluation improves their binding with DNA-gold NPs on the transducer surface and enhances the sensitivity of the developed biosensor [53]. In another example, gold NPs were used in conjugation with redox enzymes that precisely oxidize/reduce the analyte as the substrate in the reaction. On binding to the analyte, the immobilized enzyme-gold NPs eventually increase the current signal and confirm detection [51].

The AuNPs conjugated with E. coli O157: H7 antibodies were also used for detection of E. coli O157: H7 in milk. In this study, screen-printed carbon electrodes (SPCE) were fabricated with AuNPscontaining E. coli O157: H7-specific antibodies conjugated with horseradish peroxidase with a detection limit of $10^{2}-10^{7} \mathrm{cfu} \mathrm{mL} \mathrm{mL}^{-1}$ using hydrogen peroxide and ferrocene dicarboxylic acid (FeDC) as a substrate [54]. This analysis confirmed that immunosensing strips of AuNPs/FeDC-SPCE shows no specificity towards other bacteria like E. coli K12, Listeria monocytogens, S. choleraesuis and Vibrio parahaemolyticus. Hong et al. developed a selective and quick electrochemical biosensor for the detection of Norovirus (NoV) [55]. This biosensor is fabricated with a nanostructured gold electrode containing concanavalin A (ConA) as a recognition element that selectively detects NoV. In this study, the sample solution extracted from lettuce was used to measure the concentration of NoV in a realistic atmosphere for its validation with a detection limit of $\mathrm{LoD}=60$ copies $\mathrm{mL}^{-1}$. The sensor was found to be non-targeted against hepatitis A viruses (HAV) as well as hepatitis E viruses (HEV). It also showed effective thermal stability at both 4 and $25^{\circ} \mathrm{C}$, respectively.

Davis et al. developed a modified electrode-AuNPs biosensor for assessing the presence of L. monocytogenes in spiked blueberries and the detection limit was found to be $2 \log \mathrm{cfu} / \mathrm{g}$ after $1 \mathrm{~h}$ of assay [56], whereas, another group of researchers developed an enhanced AuNP aptasensor via Surface-enhanced Raman spectroscopy (SERS) for instantaneous detection of S. aureus and S. typhimurium in a spiked sample of pork [57]. In this study, the intensities of the signals for other 
bacteria like Bacillus cereus, E. coli, Shigella dysenteriae and V. parahaemolyticus were found to be very low. The outcome of this aptasensor was similar to the plate counting method exhibiting recovery between $108.33 \%$ for S. aureus and $94.12 \%$ for S. typhimurium.

\subsection{Quantum Dots}

Carbon quantum dots (CDs) are very small artificial semiconductor particles with sizes normally less than 10 nanometers. These nanoparticles are extensively used in research due to their high luminescence properties, high solubility and biocompatibility [58,59]. Carbon quantum dots (CDs) are quasi-sphere nanoparticles (diameter less than $10 \mathrm{~nm}$ ) formed from crystalline sp2 hybridization graphite cores and amorphous aggregations used in bioanalytics and biolabeling. On the other hand, graphene quantum dots (GDs) consist of single or very few graphene lattices $(<10)$. Due to bigger conjugated domains and periodic structure, the GDs are generally more crystalline than CDs. These nanostructures based on carbon are actually two distinct allotropes and both the allotropes are functionalized with oxygen-related complex surface group molecules such as carboxylates or hydroxylate derivatives that improve optical features and particle solubility [60,61]. The variability in fabrication of these materials gives rise to diverse surface functionalization and more complex hybridization in biosensor applications.

CDs have been used to detect harmful microbial culture and toxins, together with $S$. typhimurium and aflatoxin B1 (AFB1) [62,63]. Wang et al. fabricated carbon dot aptamer complexes (CD-apt) for the quantitative identification of $S$. typhimurium in eggshell and tap water solutions at a test range of $10^{3}$ to $10^{5} \mathrm{cfu} \mathrm{mL}^{-1}$ and a LOD of $50 \mathrm{cfu} \mathrm{mL}^{-1}$, for which the detection time was found to be $2 \mathrm{~h}$ without interference from E. coli $\mathrm{O} 157: \mathrm{H7}$ and S. aureus [62]. The developed sensor exhibited unvaried results in comparison to the standard plate count method in the egg sample as well as in tap water the standard plate count showed $3.6 \times 10^{4}$ and $5.9 \times 10^{4}$ results whereas for the developed sensor the readings were $3.27 \times 10^{4}$ and $5.51 \times 10^{4} \mathrm{cfu} \mathrm{mL}^{-1}$, respectively. Various trials have verified the specificity of microbial identification using biosensors in simple or complex food settings using CDs, GQDs, carbon nanotubes and semiconductors [63-65]. Wang et al. assembled CDs and AuNPs for specific AFB1 detection with the help of an aptamer and achieved a $5 \mathrm{pg} / \mathrm{mL}$ LOD (16 pM) [63]. This method was employed with actual samples like corn and peanuts, which were supplemented with varied concentrations of AFB1 in which average recovery was found to be in range of $92 \%-105 \%$. This recovery enhanced on changing the aptamer, such as ochratoxin aptamers (designed to assess fungal toxins only).

\subsection{Magnetic NPs beads as Label in Biosensor-based Detection}

Magnetic NPs are another class of nanomaterials used in biosensors which can be amended by changing the magnetic field. These NPs are clusters of magnetic beads of 50-500 nm diameters [66-68]. Magnetic NPs have emerged as one of important fabricating material to develop a flow assay as they have strong color and can separate the target material from the complex matrix. These NPs have additional benefits as it provides robust magnetic and visual signals. Various researchers have used magnetic beads to develop flow assays for detecting pathogenic bacteria $[69,70]$. Wang et al. developed antibody-covered magnetic beads of $300 \mathrm{~nm}$ and used them as indicators for spore detection of Bacillus anthracis with a detection limit of $6 \times 10^{4}$ spores/g of milk powder, $2 \times 10^{5}$ spores/g of starch, and $5 \times 10^{5}$ spores/g of baking soda, respectively [71]. The designed sensor did not show any specificity towards other Bacillus species like B. cereus, B. thuringiensis and B. mycoides. In contrast to traditional lateral-flow method, this process does not require the pre-treatment of the sample and it provides instant results for magnetic, naked-eye and optical detection within $20 \mathrm{~min}$. Suaifan et al. established a biological assay with magnetic beads for robust recognition of E. coli O157:H7 in food with detection

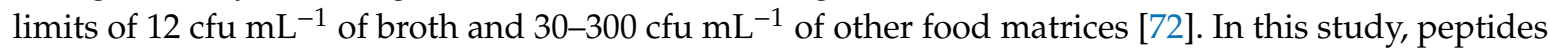
of E. coli O157:H7 (e.g., protease) were used asa substrate and conjugated with magnetic nanoparticles (MNPs). Furthermore, the crude protease synthesized by E. coli O157:H7 was down-streamed onto immobilized sensing platform and during enzymatic reaction a magnet attached on the back of sensor 
stripe, magnetizingthe cleaved MNP-peptide moieties, and generating the visual signals for qualitative assessment of the test sample within 30 seconds. The developed biosensor exhibited long-term stability, i.e., six months, and showed no specificity towards L. monocytogenes, Pseudomonas aeruginosa and S. aureus protease. On the other hand, Xia et al. developed gold magnetic nanobeads for the rapid recognition of S. choleraesuis with a detection limit of $5 \times 10^{5} \mathrm{cfu} \mathrm{mL}^{-1}$ and detection time of $20 \mathrm{~h}$ in whole milk as compared to colloid gold-based lateral flow assay with a limit of $5 \times 10^{6} \mathrm{cfu} \mathrm{mL}^{-1}$, thus confirming the superiority of magnetic beads to the colloidal gold [73].

\subsection{Dendrimers}

Dendrimers (DEN) are complex globular shaped-branched structures of 2-20 $\mathrm{nm}$ in size. The structural properties like monodispersity, manageable size, easily amendable surface functionalities, hydrophilicity, high mechanical and chemical strength makes them the preferred synthetic nanoparticle for developing biosensors [74]. The polyamidoamine (PAMAM) dendrimer is one of these which hasgained significant attention as it provides large surface areas with high number of functional groups to allow the easy binding of biological entities. It also contains mono-disperse as well as hyper-branched polymers with active functional groups present at end of dendrimer structure. These functional groups aid in immobilizing the bio-recognizing molecules, by acting as a bio-conjugating moiety and play diverse roles in biosensor technology. Electrochemical techniques like amperometric, electrochemiluminescence, impedimetric and potentiometric are generally used for estimating specific molecules using dendrimers with high selectivity and sensitivity [74].

Shiddiky et al. developed the competitive and sandwich-based bioassays for assessing DNA and protein using $\mathrm{H}_{2} \mathrm{O}_{2}$ reduction activity using a conducting polymer based on poly-5, $2^{\prime}: 5^{\prime}, 2^{\prime \prime}$-terthiophene-3'-carboxylic acid (pTTCA) [75,76]. Another biosensor, made up of the monolayer of 3G PAMAM (poly amido amine) dendrimer covalently linked by chemisorption to AuNPs/CdS nanoparticles was also developed using immobilized AuNPs on bioreceptor molecule and showed a detection limit of $450 \mathrm{aM}$ and $4 \mathrm{fg} \mathrm{mL}^{-1}$, respectively, for DNA and protein. This biosensor was 70 times more sensitive as compared to plain pTTCA layer due to AuNPsbeing attached on the pTTCA/DEN layer, which allows the binding of different proteins, avidin and hydrazine. Competitive immune interaction-based sensors have also been developed for detecting anti-microbial agents and biomarkers. The detection of AFB1, a food contaminant, was done using an aptamer-based biosensor [77]. In this study, the fourth generation polyamidoamine dendrimers were immobilized on a cystamine-covered gold electrode with further attachment with AFB1-specific DNA aptamers and showed a detection limit of LOD $=0.40 \pm 0.03 \mathrm{nM}$ at $4{ }^{\circ} \mathrm{C}$ without losing its stability for up to 60 hours. The developed sensor did not exhibit any specificity towards ochratoxin A (OTA) and was effective in detecting the AFB1 in contaminated peanuts sample.

\subsection{Silicon Nanomaterials}

Silicon nanostructure-based sensors have been developed with high specificity for use in rational fabrication biosensing and bioimaging applications [78-80]. Silicon nanomaterials can be converted into molecules knows for renal clearance as these are biodegradable in nature and are excreted from the body without any toxicity evidence [81,82]. Silicon nanoparticles (SiNPs), with a diameter of 3-10 nm, have been permitted by the Food and Drug Administration for use in human clinical trials [83]. A variety of silicon surface-enhanced Raman scattering (SERS) sensors are used in selective and sensitive detection of reproducible chemical and biological species. Pathogens with colony forming units of E. coli can be detected using biosensors based on porous silicon using chemiluminescence assay [84]. The sensitivity of this biosensor chip for E. coli was determined to be $10^{1}$ and $10^{2}$ cells for 40 and $30 \mathrm{~min}$, respectively. In another study, porous silicon was fabricated using an anodization process in an electrochemical Teflon cell [85]. In this study, platinum wire was used as a cathode and the silicon chip was used as the anode and ssDNA of S. enteritidis strain was used as a probe, for functionalized porous silicon platform. It was further observed that biosensors with porous silicon 
were highly sensitive and have more active surface area as compared to the biosensors based on planner silicon and probes specific to the targeted DNA.

\subsection{Graphene-based Nanomaterials}

Graphene-based nanomaterials are another type of material used as transducers of biosensors. These nanomaterials are generally used for the conversion of targeted and receptor molecules for detectable measurement using EDC/NHS chemistry [86]. On the other hand, graphene is the most commonly used nanomaterial for different biosensors designs with different transduction modes as it contains a large surface area, capacity to immobilize with different molecules with high electron transmission rate and electrical conductivity [87]. Graphene-based nanomaterials can also be used as a quencher to generate fluorescent transducer-based biosensors, as reduced graphene oxide (rGO), graphene (G), and graphene oxide (GO) possess a very high fluorescent quenching efficiency [88-90]. During sensor design, the detection limit of targeted molecules is affected by graphene and the sensitivity and selectivity of biosensors can also be affected by bioreceptors and G, GO or rGO sheet orientation. Differences can be observed in the sensing performance of biosensors by functional groups, graphene oxidation state, and number of layers as well as by different derivatives used.

A GO-modified iron oxid-chitosan hybrid nanocomposite-based electrochemical sensor was also used for E. coli O157:H7 detection using a specific probe oligonucleotide sequence covalently immobilized on nanocomposite films [91]. This sensor showed a detection limit of $1 \times 10^{-14} \mathrm{M}$ with a linear response to the complementary DNA in $10^{-6}$ to $10^{-14} \mathrm{M}$. Meanwhile, the specificity of the pDNA/GIOCh/ITO bioelectrode against various target DNA sequences (complementary, non-complementary and one base mismatch) and with the samples of E. coli, S. typhimurium, Neisseria meningitidis and Klebsiella pneumonia showed insignificant signal. This confirms that the fabricated biosensor has high selectivity, sensitivity and reserved significant activity (i.e., $90 \%$ of the initial activity) even after the usage of up to sixcycles. In another study involving a graphene-based biosensor designed specifically for detection by E. coli O157:H7-specific antibodies showed sensitivity in range of 10-100 cells $\mathrm{ml}^{-1}$ and did not display any specificity towards E. coli DH5 $\alpha$ strain [92]. The shelf-life of functionalized chips of this biosensor when stored at $4{ }^{\circ} \mathrm{C}$ lasted for 4 weeks. Srivastava et al. developed an electrochemical sensor for the food toxin detection by binding the monoclonal antibodies on rGO surface to AFB1 with a sensitivity of $68 \mathrm{uA} \mathrm{ng}^{-1} \mathrm{ml} \mathrm{cm}^{-2}$, and a limit of detection of $0.12 \mathrm{ng}$ $\mathrm{mL}^{-1}$ [93]. The storage stability of this immune-electrode was determined by passing the current at regular interval of 5 days for 45 days along with $25 \mathrm{ng} \mathrm{dL}^{-1}$ AFB1 and showed no substantial variation in the current, even after 45 days. In another study, a BSA/anti-AFB1/AuNPs/rGO nanocomposite-based immunosensor showed a high sensitivity of $182.4 \mu \mathrm{A} \mathrm{ng}^{-1} \mathrm{~mL}^{-1} \mathrm{~cm}^{-2}$ for the recognition of AFB1 with a limit of detection of $0.1-12 \mathrm{ng}^{-1} \mathrm{~mL}^{-1}$ and consistency up to 56 days [94].

\subsection{Conducting Polymers}

Conducting polymers withdistinctive characteristics have made these an effective alternative for some materials currently used in the biosensor fabrication. Polymers are good insulators and some polymers are found to have good conducting properties due to their combination of metallic and semiconductor characteristics. There are varieties of conducting polymers used in different applications [95]. Out of these, polyaniline, polythiophene, and polypyrrole are used as nanomaterials and show biocompatibility and can reduce the leading disturbances affecting the working environment and these also help in preventing the electrodes from fouling [96,97]. Only polyaniline and polypyrrole are extensively used for the detection of foodborne pathogens. Conducting polymers are used as an excellent immobilizing platform with biomolecules at electrodes to deliver better signal transduction, high sensitivity, selectivity, durability, biocompatibility and flexibility [98,99].

Tully et al. reported direct immunosensor use for the identification of a cell-surface protein on L. monocytogenes with label-free immunosensing of Internalin B (InlB) with a limit of detection for InlB at $4.1 \mathrm{pg} \mathrm{mL}^{-1}$ [99]. Muhammad-Tahir and Alocilja reported the performance of a biosensor 
based on electrochemical transducer using polyaniline in measuring an immune reaction for detecting $7.8 \times 10^{1} \mathrm{cfu} / \mathrm{mL}$ of $E$. coli O157:H7 in $10 \mathrm{~min}$ [100]. Polyaniline was also reported as an identifier for the electrochemical sandwich immunoassay of E. coli O157:H7 detection in fresh produce such as lettuce, alfalfa sprouts, and straw-berries and with an average of $81 \mathrm{cfu} \mathrm{mL}^{-1}$ in nine samples in 6 mins [101]. Sheikhzadeh et al. used a label-free impedimetric biosensor for the detection of $S$. typhimurium based on the effect of the aptamer/target response to the central conjugation of poly [pyrrole-co-3-carboxyl-pyrrole] copolymer-based aptamer to its electrical characteristics [102]. In this study, the S. typhimurium was detected with high selectivity over other pathogens at a concentration range of $10^{2}-10^{8} \mathrm{cfu} \mathrm{mL}^{-1}$ with a limit of detection of $3 \mathrm{cfu} \mathrm{mL}^{-1}$. The developed aptasensor showed high selectivity towards $S$. typhimurium on comparing its detection value with other potential model strains viz. E. coli 375, E. coli 797, E. coli 3274, Enterobacter, and Citrobacter. Moreover, the developed aptasensor showed robust detection of $S$. typhimurium in $45 \mathrm{~min}$ in spiked apple juice.

\section{Current Status and Future Prospects}

Various developments in nanotechnology have shown its proficiency in detecting pathogenic microbes and resulted in an answer to different problems related to biotransformation and metabolism of ingested NPs (Table 4). 
Table 4. Types of nanomaterials used in sensor fabrication for foodborne pathogens and their toxins detection.

\begin{tabular}{|c|c|c|c|c|c|c|c|}
\hline Biosensors & Sensing Platform & $\begin{array}{l}\text { Nanomaterials used in } \\
\text { Biosensor Fabrication }\end{array}$ & Food Matrix & Pathogens/Toxins & Detection Limit & Analysis Time & Ref \\
\hline $\begin{array}{l}\text { Electrochemical } \\
\text { biosensor }\end{array}$ & Screen printed carbon electrode & $\begin{array}{l}\text { PLA-AuNPs (polylactic } \\
\text { acid-stabilized gold } \\
\text { nanoparticles) }\end{array}$ & Shellfish & Standard Vibrio parahemolyticus & $2.16 \times 10^{-6} \mu \mathrm{M}$ & NS & [103] \\
\hline Electrochemical DNA biosensor & Screen printed carbon electrode & PLA-AuNPs & $\begin{array}{l}\text { Cockle } \\
\text { Ground beef, }\end{array}$ & Standard Vibrio parahemolyticus & $5.3 \times 10^{-12}$ & $10 \mathrm{~min}$ & [104] \\
\hline Paper-based biosensor & Gold electrode & Magnetic beads & $\begin{array}{l}\text { Turkey sausage, } \\
\text { Lettuce and Milk }\end{array}$ & Standard Staphylococcus aureus & $40 \mathrm{cfu} / \mathrm{mL}$ & $1 \min$ & [105] \\
\hline Aptamer-based biosensor & Gold electrode & $\begin{array}{c}\text { Cys-PAMAM } \\
\text { (cystamine-poly(amido-amine) } \\
\text { dendrimers) }\end{array}$ & Peanuts & Aflatoxin B1 & $0.40 \mathrm{nM}$ & $10 \mathrm{~min}$ & [77] \\
\hline $\begin{array}{l}\text { Electrochemical } \\
\text { immunosensor }\end{array}$ & Graphite electrode & $\begin{array}{c}\text { Carboxylic acid-MWCNT } \\
\text { (multiwalled carbon nanotubes) }\end{array}$ & Milk & $\begin{array}{c}\text { Standard Salmonella, Campylobacter } \\
\text { and Escherichia coli }\end{array}$ & $400-800 \mathrm{cfu} / \mathrm{mL}$ & $30 \mathrm{~min}$ & [106] \\
\hline $\begin{array}{l}\text { Electrochemical impedance } \\
\text { Immunosensor }\end{array}$ & Glassy carbon electrode & AuNPs-MWCNT-PAMAM & Milk & Standard Salmonella typhimurium & $5.0 \times 10^{2} \mathrm{cfu} / \mathrm{mL}$ & NS & [107] \\
\hline $\begin{array}{l}\text { Lytic phage-based } \\
\text { magnetoelastic biosensors }\end{array}$ & $\begin{array}{l}\text { Iron-Nickel Base Magnetic } \\
\text { ribbon }\end{array}$ & Cr-Au layer (Chromium) & Spinach Leaves & $\begin{array}{c}\text { Standard Staphylococcus aureus } \\
\text { (MRSA) }\end{array}$ & $\begin{array}{l}1.76 \log \mathrm{cfu} / 25 \mathrm{~mm}^{2} \\
\text { surface of spinach }\end{array}$ & $30 \mathrm{~min}$ & [108] \\
\hline $\begin{array}{l}\text { Amperometric immunosensing } \\
\text { strips }\end{array}$ & Screen printed carbon electrode & AuNPs & Milk & Standard Escherichia coli O157:H7 & $50 \mathrm{cfu} / \mathrm{strip}$ in milk & $1 \mathrm{~h}$ & [54] \\
\hline Impedimetric biosensor & Gold disk electrodes & Pyrrole-3-carboxylic acid & Apple Juice & Standard Salmonellatyphimurium & $3 \mathrm{cfu} / \mathrm{mL}$ & $45 \mathrm{~min}$ & [102] \\
\hline Amperometry biosensor & Glassy carbon disc electrode & Polypyrrole & NA & $\begin{array}{l}\text { Laboratory isolates of Listeria } \\
\text { monocytogenes }\end{array}$ & $10^{5} \mathrm{cfu} / \mathrm{mL}$ & $30 \mathrm{~min}$ & [109] \\
\hline Colorimetric aptasensor & Magnetic beads & NA (not applicable) & Salmon & Standard Vibrio parahemolyticus & $10^{2}-10^{7} \mathrm{cfu} / \mathrm{mL}$ & NS & [110] \\
\hline Fluorescence immunoassay & $\begin{array}{l}\text { CdTe quantum dots (Cadmium } \\
\text { telluride) }\end{array}$ & NA & Whole milk & Standard Escherichia coli O157:H7 & $5 \times 10^{2}-10^{7} \mathrm{cfu} / \mathrm{mL}$ & NS & [111] \\
\hline Lateral flow biosensor & AuNPs (Gold nanoparticles) & NA & Milk & Standard Salmonella enteriditis & $10^{1} \mathrm{cfu} / \mathrm{mL}$ & $10 \mathrm{~min}$ & [112] \\
\hline Mid-Infrared pathogen sensor & Magnetic nanoparticles & NA & Spinach and Milk & Standard bacterial cultures & $10^{4}-10^{5} \mathrm{cfu} / \mathrm{mL}$ & $30 \mathrm{~min}$ & [113] \\
\hline Aptamer-based biosensor & AuNPs & NA & Milk powder & $\begin{array}{c}\text { Laboratory isolates of Escherichia coli } \\
\text { O157:H7 }\end{array}$ & $10 \mathrm{cfu} / \mathrm{mL}$ & $30 \mathrm{~min}$ & [114] \\
\hline Electrochemical biosensor & Gold electrode & NA & Lettuce & $\begin{array}{l}\text { Laboratory isolates of Norovirus } \\
\text { Laboratory isolates of }\end{array}$ & 60 copies/mL & $1 \mathrm{~h}$ & [55] \\
\hline Gold nanoprobe & AuNPs & NA & NS (not specified) & $\begin{array}{l}\text { Staphylococcus aureus, } \\
\text { Listeria monocytogenes, } \\
\text { Salmonella spp. }\end{array}$ & $123 \mathrm{fg} / \mu \mathrm{L}$ & $30 \mathrm{~min}$ & [115] \\
\hline $\begin{array}{l}\text { Fluorometric graphene } \\
\text { oxide-based assay }\end{array}$ & Graphene oxide & NA & NA & Standard Salmonella enteriditis & $25 \mathrm{cfu} / \mathrm{mL}$ & NS & [116] \\
\hline Chemiluminescent aptasensor & $\begin{array}{c}\mathrm{Fe}_{3} \mathrm{O}_{4} \mathrm{GO} \text { NPs (Graphene } \\
\text { oxide/iron nanoparticles) }\end{array}$ & NA & NA & $\begin{array}{c}\text { Standard pre killed Escherichia coli } \\
\text { O157:H7 }\end{array}$ & $4.5 \times 10^{3} \mathrm{cfu} / \mathrm{mL}$ & $1 \mathrm{~h}$ & [117] \\
\hline $\begin{array}{l}\text { Magnetoresistive-based } \\
\text { immunoassay }\end{array}$ & $\begin{array}{c}\mathrm{Fe}_{2} \mathrm{O}_{3} \text { superparamagnetic } \\
\text { particles }\end{array}$ & NA & NA & Standard Aflatoxins B1, Zearalenone & $50 \mathrm{pg} / \mathrm{mL}$ & $10 \mathrm{~min}$ & [118] \\
\hline $\begin{array}{l}\text { Goldnanoprobe-nucleic acid } \\
\text { sequence-based amplification }\end{array}$ & Au colloid & NA & NA & Standard Salmonella strains & $5 \mathrm{cfu} / \mathrm{mL}$ & $80 \mathrm{~min}$ & [119] \\
\hline Bioconjugate nanocapsules & AuNPs & NA & NA & Listeria monocytogenes & $\begin{array}{c}8.1 \times 10^{5} \mathrm{cfu} / \mathrm{ml} \text { and } 2.6 \times \\
10^{7} \mathrm{cfu} / \mathrm{mL}\end{array}$ & $5 \mathrm{~min}$ & [120] \\
\hline $\begin{array}{l}\text { Silicon-based DNA } \\
\text { biosensor }\end{array}$ & Silicon wafer & NA & NS & $\begin{array}{c}\text { Laboratory isolates of Salmonella } \\
\text { enteritidis }\end{array}$ & $1 \mathrm{ng} / \mathrm{mL}$ & NS & [85] \\
\hline
\end{tabular}




\section{Conclusions}

The application of sensors in food processing industries has also changed the current trend as these can identify the various contaminants formed within the food chain with high sensitivity. The advancements in diagnostics have increased the demand for portable devices for robust and precise detection in food industries. Nano-sensors have the potential to meet both the demand of miniaturization and low-cost analytical devices. In the past few years, applications of e-nose technologies have come through advances in sensor design, material improvements, software innovations and progress in micro-circuitry design and systems integration. There is significant interest in methods for the early detection of quality changes in food products. The development of electronic nose technology has stimulated interest in the use of characteristic volatiles and odors as a rapid, early indication of deterioration in food quality [121,122]. The research on nanotechnology has progressed so much that it has encouraged the expansion of nanosensors for the detection of foodborne pathogens with high improvements overthe conventional methods. Ultrasensitive transglutaminase-based nanosensors used for early diagnosis of celiac diseases in human and identification of foodborne pathogens and food-related disorders using biosensor are some specific examples of biosensor use [123-125]. The extensive research progress in nanotechnology for nanomaterial exploration and the development of new mechanisms in the future will enable researchers to develop highly sensitive, specific and unobtrusive nanosensors for analyzing food-borne microbes at an affordable cost.

Author Contributions: H.K., S.K.B., K.S., D.K. and K.K. conceptualized the manuscript. H.K., K.S. wrote the manuscript. K.K., S.K.B., T.C.B. and R.V. assisted in writing, updated information and edited the manuscript. K.K., A.K., T.C.B., R.V., and D.K. contributed in critically revising the draft and updating the manuscript for publication. All authors have read and agreed to the published version of the manuscript.

Funding: Supported by Excellence project FIM UHK.

Conflicts of Interest: The authors declare no conflicts of interest.

\section{References}

1. Vo-Dinh, T.; Cullum, B.M.; Stokes, D.L. Nanosensors and biochips: Frontiers in biomolecular diagnostics. Sens. Actuators B Chem. 2001, 74, 2-11. [CrossRef]

2. Jain, K.K. Nanodiagnostics: Application of nanotechnology in molecular diagnostics. Expert Rev. Mol. Diagn. 2003, 3, 153-161. [CrossRef]

3. Haruyama, T. Micro- and nanobiotechnology for biosensing cellular responses. Adv. Drug Deliv. Rev. 2003, 55, 393-401. [CrossRef]

4. World Health Organization. Estimating the Burden of Foodborne Diseases. Available online: https: //www.who.int/activities/estimating-the-burden-of-foodborne-diseases (accessed on 21 January 2020).

5. Fratamico, P.M.; Gehring, A.G.; Karns, J.; Van Kessel, J. Detecting pathogens in cattle and meat. In Improving the Safety of Fresh Meat; EditorSofos, J., Ed.; Woodhead Publishing: Cambridge, UK, 2005; pp. 24-55.

6. Lazcka, O.; Campo, F.J.D.; Muňoz, F.X. Pathogen detection: A perspective of traditional methods and biosensors. Biosens. Bioelectron. 2007, 22, 1205-1217. [CrossRef] [PubMed]

7. Bhunia, A.K. Biosensors and bio-based methods for the separation and detection of foodborne pathogens. Adv. Food Nutr. Res. 2008, 54, 1-44. [PubMed]

8. Kalpana, S.R.; Anshul, S.; Rao, N.H. Nanotechnology in food processing sector-An assessment of emerging trends. J. Food Sci. Technol. 2013, 50, 831-841. [CrossRef] [PubMed]

9. Gabig-Ciminska, M. Developing nucleic acid-based electrical detection systems. Microb. Cell Fact. 2006, 5, 9. [CrossRef] [PubMed]

10. Syed, M.A.; Bokhari, S.H.A. Gold nanoparticle based microbial detection and identification. J. Biomed. Nanotechnol. 2011, 7, 229-237. [CrossRef]

11. Doria, G.; Conde, J.; Veigas, B.; Giestas, L.; Almeida, C.; Assuncao, M.; Joao, R.; Pedro, V.B. Noble metal nanoparticles for biosensing applications. Sensors 2012, 12, 1657-1687. [CrossRef]

12. Yeh, Y.C.; Creran, B.; Rotello, V.M. Gold Nanoparticles: Preparation, properties, and applications in bionanotechnology. Nanoscale 2012, 4, 1871-1880. [CrossRef] 
13. Baughman, R.H.; Zakhidov, A.A.; Heer, W.A.D. Carbon Nanotubes-the route toward applications. Science 2002, 297, 787-792. [CrossRef] [PubMed]

14. Eatemadi, A.; Daraee, H.; Karimkhanloo, H.; Kouhi, M.; Zarghami, N.; Akbarzadeh, A.; Abasi, M.; Hanifehpour, Y.; Joo, S.W. Carbon nanotubes: Properties, synthesis, purification, and medical applications. Nanoscale Res. Lett. 2014, 9, 393. [CrossRef] [PubMed]

15. Akbarzadeh, A.; Samiei, M.; Davaran, S. Magnetic nanoparticles: Preparation, physical properties, and applications in biomedicine. Nanoscale Res. Lett. 2012, 7, 144. [CrossRef] [PubMed]

16. Huan, C.; Shu-Qing, S. Silicon nanoparticles: Preparation, properties, and applications. Chin. Phys. B 2014, 23, 088102.

17. Smith, A.T.; LaChance, A.M.; Zeng, S.; Liu, B.; Sun, L. Synthesis, properties, and applications of graphene oxide/reduced grapheme oxide and their nanocomposites. Nano Mater. Sci. 2019, 1, 31-47. [CrossRef]

18. Klajnert, B.; Bryszewska, M. Dendrimers: Properties and applications. Acta Biochim. Pol. 2001, 48, $199-208$. [CrossRef]

19. Abbasi, E.; Aval, S.F.; Akbarzadeh, A.; Milani, M.; Nasrabadi, H.T.; Joo, S.W.; Hanifehpour, Y.; Nejati-Koshki, K.; Pashaei-Asl, R. Dendrimers: Synthesis, applications, and properties. Nanoscale Res. Lett. 2014, 9, 247. [CrossRef]

20. Kumar, R.; Singh, S.; Yadav, B.C. Conducting polymers: Synthesis, properties and applications. Int. Adv. Res. J. Sci. Eng. Technol. 2015, 2, 110-124.

21. Gerwen, P.V.; Laureyn, W.; Laureys, W.; Huyberechts, G.; Beecka, M.O.D.; Baert, K.; Suls, J.; Sansen, W.; Jacobs, P.; Hermans, L.; et al. Nanoscaled interdigitated electrode arrays for biochemical sensors. Sens. Actuators B Chem. 1998, 49, 73-80. [CrossRef]

22. Pak, S.C.; Penrose, W.; Hesketh, P.J. An ultrathin platinum film sensor to measure biomolecular binding. Biosens. Bioelectron. 2001, 16, 371-379. [CrossRef]

23. Bhushan, B. Nanotribology and nanomechanics of MEMS/NEMS and BioMEMS/BioNEMS materials and devices. Microelectron. Eng. 2007, 84, 387-412. [CrossRef]

24. Zeng, S.; Yong, K.T.; Roy, I.; Dinh, X.Q.; Yu, X.; Luan, F. A review on functionalized gold nanoparticles for biosensing applications. Plasmonics 2011, 6, 491-506. [CrossRef]

25. Nath, N.; Chilkoti, A. A colorimetric gold nanoparticle sensor to interrogate biomolecular interactions in real time on a surface. Anal. Chem. 2002, 74, 504-509. [CrossRef] [PubMed]

26. Haes, A.J.; Duyne, R.P.V. A nanoscale optical biosensor: Sensitivity and selectivity of an approach based on the localized surface plasmon resonance spectroscopy of triangular silver nanoparticles. J. Am. Chem. Soc. 2002, 124, 10596-10604. [CrossRef] [PubMed]

27. Kelly, K.L.; Coronado, E.; Zhao, L.L.; Schatz, G.C. The optical properties of metal nanoparticles: The influence of size, shape, and dielectric environment. J. Phys. Chem. B 2003, 107, 668-677. [CrossRef]

28. Zhu, Y.; Zhao, Q.; Li, Y.; Cal, X.; Li, W. The interaction and toxicity of multi-walled carbon nanotubes with Stylonychiamytilus. J. Nanosci. Nanotechnol. 2006, 6, 1357-1364. [CrossRef]

29. Fujitani, T.; Ohyama, K.; Hirose, A.; Nishimura, T.; Nakae, D.; Ogata, A. Teratogenicity of multi-wall carbon nanotube (MWCNT) in ICR mice. J. Toxicol. Sci. 2012, 37, 81-89. [CrossRef]

30. Qi, W.; Bi, J.; Zhang, X.; Wang, J.; Wang, J.; Liu, P.; Li, Z.; Wu, W. Damaging effects of multi- walled carbon nanotubes on pregnant mice with different pregnancy times. Sci. Rep. 2014, 4, 4352. [CrossRef]

31. Vlaanderen, J.; Pronk, A.; Rothman, N.; Hildesheim, A.; Silverman, D.; Hosgood, H.D.; Spaan, S.; Kuijpers, E.; Godderis, L.; Hoet, P.; et al. A cross-sectional study of changes in markers of immunological effects and lung health due to exposure to multi-walled carbon nanotubes. Nanotoxicology 2017, 11, 395-404. [CrossRef]

32. Pietroiusti, A.; Massimiani, M.; Fenoglio, I.; Colonna, M.; Valentini, F.; Palleschi, G.; Camaioni, A.; Magrini, A.; Siracusa, G.; Bergamaschi, A.; et al. Low doses of pristine and oxidized single-wall carbon nanotubes affect mammalian embryonic development. ACS Nano 2011, 5, 4624-4633. [CrossRef]

33. Philbrook, N.A.; Walker, V.K.; Afrooz, A.R.; Saleh, N.B.; Winn, L.M. Investigating the effects of functionalized carbon nanotubes on reproduction and development in Drosophila melanogaster and CD-1mice. Reprod. Toxicol. 2011, 32, 442-448. [CrossRef] [PubMed]

34. Karathanasis, A.D. Subsurface migration of copper and zinc mediated by soil colloids. Soil Sci. Soc. Am. J. 1999, 63, 830-838. [CrossRef] 
35. Chu, M.; Wu, Q.; Yang, H.; Yuan, R.; Hou, S.; Yang, Y.; Zou, Y.; Xu, S.; Xu, K.; Ji, A.; et al. Transfer of quantum dots from pregnant mice to pups across the placental barrier. Small 2010, 6, 670-678. [CrossRef] [PubMed]

36. Zhang, X.D.; Wu, H.Y.; Wu, D.; Wang, Y.Y.; Chang, J.H.; Zhai, Z.B.; Meng, A.M.; Liu, P.X.; Zhang, L.A.; Fan, F.Y. Toxicologic effects of gold nanoparticles in vivo by different administration routes. Int. J. Nanomed. 2010, 5, 771-781. [CrossRef] [PubMed]

37. Vaitkuviene, A.; Kaseta, V.; Voronovic, J.; Ramanauskaite, G.; Biziuleviciene, G.; Ramanaviciene, A.; Ramanavicius, A. Evaluation of cytotoxicity of polypyrrole nanoparticles synthesized by oxidative polymerization. J. Hazard. Mater. 2013, 250, 167-174. [CrossRef]

38. Sharifabadi, M.A.; Koohi, M.K.; Zayerzadeh, E.; Hablolvarid, M.H.; Hassan, J.; Seifalian, A.M. In vivo toxicological evaluation of graphene oxide nanoplatelets for clinical application. Int. J. Nanomed. 2018, 13, 4757-4769. [CrossRef]

39. Awaad, A. Histopathological and immunological changes induced by magnetite nanoparticles in the spleen, liver and genital tract of mice following intravaginal instillation. J. Basic Appl. Zool. 2015, 71, 32-47. [CrossRef]

40. Mukherjee, S.P.; Lyng, F.M.; Garcia, A.; Davoren, M.; Byrne, H.J. Mechanistic studies of in vitro cytotoxicity of poly(amidoamine) dendrimers in mammalian cells. Toxicol. Appl. Pharmacol. 2010, 248, 259-268. [CrossRef]

41. University of Wollongong. Available online: https:/documents.uow.edu.au/content/groups/public/@web/ @ohs/documents/doc/uow136509.pdf (accessed on 5 October 2019).

42. Department of Science \& Technology. Available online: http://nanomission.gov.in/What_new/Draft_ Guidelines_and_Best_Practices.pdf (accessed on 4 October 2019).

43. Concordia University. Available online: https://www.concordia.ca/content/dam/concordia/services/safety/ docs/EHS-DOC-035_NanomaterialsSafetyGuidelines.pdf (accessed on 2 October 2019).

44. European Commission. Available online: https://osha.europa.eu/en/legislation/guidelines/guidanceprotection-health-and-safety-workers-potential-risks-related (accessed on 2 October 2019).

45. World Health Organization. Available online: https://apps.who.int/iris/bitstream/handle/10665/259671/ 9789241550048-eng.pdf?sequence=1 (accessed on 7 October 2019).

46. Food and Drug Administration. Available online: https://www.fda.gov/media/83957/download (accessed on 4 October 2019).

47. Pandit, S.; Dasgupta, D.; Dewan, N.; Ahmed, P. Nanotechnology based biosensors and its application. PharamInnov. J. 2016, 5, 18-25.

48. Weber, J.E.; Pillai, S.; Rama, M.K.; Kumar, A.; Singh, S.R. Electrochemical impedance-based DNA sensor using a modified single walled carbon nanotube electrode. Mater. Sci. Eng. C 2011, 31, 821-825. [CrossRef]

49. Hasan, M.R.; Pulingam, T.; Appaturi, J.N.; Zifruddin, A.N.; The, S.J.; Lim, T.W.; Ibrahim, F.; Leo, B.F.; Thong, K.L. Carbon nanotube-based aptasensor for sensitive electrochemical detection of whole-cell Salmonella. Anal. Biochem. 2018, 554, 34-43. [CrossRef] [PubMed]

50. Yamada, K.; Kim, C.T.; Kim, J.H.; Chung, J.H.; Lee, H.G.; Jun, S. Single walled carbon nanotube-based junction biosensor for detection of Escherichia coli. PLoS ONE 2014, 9, e105767. [CrossRef] [PubMed]

51. Sperling, R.A.; Rivera, P.G.; Zhang, F.; Zanella, M.; Parak, W.J. Biological applications of gold nanoparticles. Chem. Soc. Rev. 2008, 37, 1896-1908. [CrossRef] [PubMed]

52. Guo, S.; Wang, E. Synthesis and electrochemical applications of gold nanoparticles. Anal. Chim. Acta 2007, 598, 181-192. [CrossRef] [PubMed]

53. Zhang, Y. Electrochemical DNA biosensors based on gold nanoparticles/cysteamine/poly (glutamic acid) modified electrode. Am. J. Biomed. Sci. 2007, 1, 115-125. [CrossRef]

54. Lin, Y.H.; Chen, S.H.; Chuang, Y.C.; Lu, Y.C.; Shen, T.Y.; Chang, C.A.; Lin, C.S. Disposable amperometricimmunosensing strips fabricated by Au nanoparticles-modified screen-printed carbon electrodes for the detection of foodborne pathogen Escherichia coli O157:H7. Biosens. Bioelectron. 2008, 23, 1832-1837. [CrossRef]

55. Hong, S.A.; Kwon, J.; Kim, D.; Yang, S. A rapid, sensitive and selective electrochemical biosensor with concanavalin A for the preemptive detection of norovirus. Biosens. Bioelectron. 2015, 64, 338-344. [CrossRef]

56. Davis, D.; Guo, X.; Musavi, L.; Lin, C.S.; Chen, S.H.; Wu, V.C.H. Gold nanoparticle-modified carbon electrode biosensor for the detection of Listeria monocytogenes. Ind. Biotechnol. 2013, 9, 31-36. [CrossRef] 
57. Zhang, H.; Ma, X.; Liu, Y.; Duan, N.; Wu, S.; Wang, Z.; Xu, B. Gold nanoparticles enhanced SERS aptasensor for the simultaneous detection of Salmonella typhimurium and Staphylococcus aureus. Biosens. Bioelectron. 2015, 15, 872-877. [CrossRef]

58. Xu, X.; Ray, R.; Gu, Y.; Ploehn, H.J.; Gearheart, L.; Raker, K.; Crivens, W.A. Electrophoretic analysis and purification of fluorescent single-walled carbon nanotube fragments. J. Am. Chem. Soc. 2004, 126, 12736-12737. [CrossRef]

59. Sun, Y.P.; Zhou, B.; Lin, Y.; Wang, W.; Fernando, K.A.S.; Pathak, P.; Meziani, M.J.; Harruff, B.A.; Wang, X.; Wang, H.; et al. Quantum-sized carbon dots for bright and colorful photoluminescence. J. Am. Chem. Soc. 2006, 128, 7756-7757. [CrossRef] [PubMed]

60. Li, H.; Kang, Z.; Liu, Y.; Lee, S.T. Carbon nanodots: Synthesis, properties and applications. J. Mater. Chem. 2012, 22, 24230-24253. [CrossRef]

61. Ding, C.; Zhu, A.; Tian, Y. Functional surface engineering of C-dots for fluorescent biosensing and in vivobioimaging. Acc. Chem. Res. 2014, 47, 20-30. [CrossRef] [PubMed]

62. Wang, R.; Xu, Y.; Zhang, T.; Jiang, Y. Rapid and sensitive detection of Salmonella typhimurium using aptamer-conjugated carbon dots as fluorescence probe. Anal. Methods 2015, 7, 1701-1706. [CrossRef]

63. Wang, B.; Chen, Y.; Wu, Y.; Weng, B.; Liu, Y.; Lu, Z.; Li, C.M.; Yu, C. Aptamer induced assembly of fluorescent nitrogen-doped carbon dots on gold nanoparticles for sensitive detection of AFB 1. Biosens. Bioelectron. 2016, 78, 23-30. [CrossRef] [PubMed]

64. Zhao, Y.; Ye, M.; Chao, Q.; Jia, N.; Ge, Y.; Shen, H. Simultaneous detection of multifood-borne pathogenic bacteria based on functionalized quantum dots coupled with immunomagnetic separation in food samples. J. Agric. Food Chem. 2008, 57, 517-524. [CrossRef]

65. Mandal, T.K.; Parvin, N. Rapid detection of bacteria by carbon quantum dots. J. Biomed. Nanotechnol. 2011, 7, 846-848. [CrossRef]

66. Liu, C.Y.; Jia, Q.J.; Yang, C.H.; Qiao, R.R.; Jing, L.H.; Wang, L.B.; Xu, C.L.; Gao, M.Y. Lateral flow immunochromatographic assay for sensitive pesticide detection by using $\mathrm{Fe}_{3} \mathrm{O}_{4}$ nanoparticle aggregates as color reagents. Anal. Chem. 2011, 83, 6778-6784. [CrossRef]

67. Quesada-González, D.; Merkoçi, A. Nanoparticle-based lateral flow biosensors. Biosens. Bioelectron. 2015, 73, 47-63. [CrossRef]

68. Huang, X.; Aguilar, Z.P.; Xu, H.; Lai, W.; Xiong, Y. Membrane-based lateral flow immunochromatographic strip with nanoparticles as reporters for detection: A review. Biosens. Bioelectron. 2016, 75, 166-180. [CrossRef]

69. Ren, W.; Cho, H.; Zhou, Z.; Irudayaraj, J. Ultrasensitive detection of microbial cells usingmagnetic focus enhanced lateral flow sensors. Chem. Commun. 2016, 52, 4930-4933. [CrossRef] [PubMed]

70. Qiao, Z.H.; Lei, C.Y.; Fu, Y.C.; Li, Y.B. Rapid and sensitive detection of E. coli O157:H7 based on antimicrobial peptide functionalized magnetic nanoparticles and urease-catalyzed signal amplification. Anal. Methods 2017, 9, 5204-5210. [CrossRef]

71. Wang, D.B.; Tian, B.; Zhang, Z.P.; Wang, X.Y.; Fleming, J.; Bi, L.J.; Yang, R.F.; Zhang, X.E. Detection of Bacillus anthracis spores by super-paramagnetic lateral-flow immunoassays based on "road closure". Biosens. Bioelectron. 2015, 67, 608-614. [CrossRef] [PubMed]

72. Suaifan, G.; Alhogail, S.; Zourob, M. Paper-based magnetic nanoparticle-peptide probe for rapid and quantitative colorimetric detection of Escherichia coli O157:H7. Biosens. Bioelectron. 2017, 92, 702-708. [CrossRef]

73. Xia, S.; Yu, Z.; Liu, D.; Xu, C.; Lai, W. Developing a novel immunochromatographic test strip with gold magnetic bifunctional nanobeads (GMBN) for efficient detection of Salmonella choleraesuis in milk. Food Cont. 2016, 59, 507-512. [CrossRef]

74. Bahadir, E.B.; Sezgintürk, M.K. Poly (amidoamine) (PAMAM): An emerging material for electrochemical bio (sensing) applications. Talanta 2016, 148, 427-438. [CrossRef]

75. Shiddiky, M.J.A.; Rahman, M.A.; Shim, Y.B. Hydrazine-catalyzed ultrasensitive detection of DNA and proteins. Anal. Chem. 2007, 79, 6886-6890. [CrossRef]

76. Shiddiky, M.J.A.; Rahman, M.A.; Cheol, C.S.; Shim, Y.B. Fabrication of disposable sensors for biomolecule detction using hydrazine electrocatalyst. Anal. Biochem. 2008, 379, 170-175. [CrossRef]

77. Castillo, G.; Spinella, K.; Poturnayová, A.; Šnejdárková, M.; Mosiello, L.; Hianik, T. Detection of aflatoxin $B_{1}$ by aptamer-based biosensor using PAMAM dendrimers as immobilization platform. Food Cont. 2015, 52, 9-18. [CrossRef] 
78. Wang, Y.; Wang, T.; Da, P.; Xu, M.; Wu, H.; Zheng, G. Silicon nanowires for biosensing, energy storage, and conversion. Adv. Mater. 2013, 25, 5177-5195. [CrossRef]

79. Nishimura, H.; Ritchie, K.; Kasai, R.S.; Goto, M.; Morone, N.; Sugimura, H.; Tanaka, K.; Sase, I.; Yoshimura, A.; Nakano, Y.; et al. Biocompatible fluorescent silicon nanocrystals for single-molecule tracking and fluorescence imaging. J. Cell Biol. 2013, 202, 967-983. [CrossRef] [PubMed]

80. Lai, C.H.; Hütter, J.; Hsu, C.W.; Tanaka, H.; Varela-Aramburu, S.; Cola, L.; Lepenies, B.; Seeberger, P.H. Analysis of carbohydrate-carbohydrate interactions using sugar-functionalized silicon nanoparticles for cell imaging. Nano Lett. 2016, 16, 807-811. [CrossRef] [PubMed]

81. Park, J.H.; Gu, L.; von-Maltzahn, G.; Ruoslahti, E.; Bhatia, S.N.; Sailor, M.J. Biodegradable luminescent porous silicon nanoparticles for in vivo applications. Nat. Mater. 2009, 8, 331-336. [CrossRef]

82. Chiappini, C.; De-Rosa, E.; Martinez, J.O.; Liu, X.; Steele, J.; Stevens, M.M.; Tasciotti, E. Biodegradable silicon nanoneedles delivering nucleic acids intracellularly induce localized in vivo neovascularization. Nat. Mater. 2015, 14, 532-539. [CrossRef]

83. Phillips, E.; Penate-Medina, O.; Zanzonico, P.B.; Carvajal, R.D.; Mohan, P.; Ye, Y.; Humm, J.; Gönen, M.; Kalaigian, H.; Schöder, H.; et al. Clinical translation of an ultrasmall inorganic optical-PET imaging nanoparticle probe. Sci. Transl. Med. 2014, 6, 260ra149. [CrossRef]

84. Mathew, F.P.; Alocilja, E.C. Porous silicon-based biosensor for pathogen detection. Biosens. Bioelectron. 2005, 20, 1656-1661. [CrossRef]

85. Zhang, D.; Alocilja, E.C. Characterization of nanoporous silicon-based DNA biosensor for the detection of Salmonella enteritidis. IEEE Sens. J. 2008, 8, 775-780. [CrossRef]

86. Pumera, M. Graphene in biosensing. Mater. Today 2011, 14, 308-315. [CrossRef]

87. Rao, C.N.R.; Sood, A.K.; Subrahmanyam, K.S.; Govindaraj, A. Graphene: The new two-dimensional nanomaterial. Angew. Chem. Int. Ed. 2009, 48, 7752-7777. [CrossRef]

88. Kasry, A.; Ardakani, A.A.; Tulevski, G.S.; Menges, B.; Copel, M.; Vyklicky, L. Highly efficient fluorescence quenching with graphene. J. Phys. Chem. C 2012, 116, 2858-2862. [CrossRef]

89. Wu, X.; Xing, Y.; Zeng, K.; Huber, K.; Zhao, J.X. Study of fluorescence quenching ability of graphene oxide with a layer of rigid and tunable silica spacer. Langmuir 2018, 34, 603-611. [CrossRef] [PubMed]

90. Batır, G.G.; Arık, M.; Caldıran, Z.; Turut, A.; Aydogan, S. Synthesis and characterization of reduced graphene oxide/rhodamine 101 (rGO-Rh101) nanocomposites and their heterojunction performance in rGORh101/p-Si device configuration. J. Electron. Mater. 2018, 47, 329-336. [CrossRef]

91. Tiwari, I.; Singh, M.; Pandey, C.M.; Sumana, G. Electrochemical genosensor based on graphene oxide modified iron oxide-chitosan hybrid nanocomposite for pathogen detection. Sens. Actuators B Chem. 2015, 206, 276-283. [CrossRef]

92. Pandey, A.; Gurbuz, Y.; Ozguz, V.; Niazi, J.H.; Qureshi, A. Graphene-interfaced electrical biosensor for label-free and sensitive detection of foodborne pathogenic E. coli O157:H7. Biosens. Bioelectron. 2017, 91, 225-231. [CrossRef] [PubMed]

93. Srivastava, S.; Kumar, V.; Ali, M.A.; Solanki, P.R.; Srivastava, A.; Sumana, G.; Saxena, P.S.; Joshi, A.G.; Malhotra, B.D. Electrophoretically deposited reduced graphene oxide platform for food toxin detection. Nanoscale 2013, 5, 3043-3051. [CrossRef]

94. Srivastava, S.; Abraham, S.; Singh, C.; Ali, M.A.; Srivastava, A.; Sumana, G.; Malhotra, B.D. Protein conjugated carboxylatedgold@reduced graphene oxide for aflatoxin B1 detection. RSC Adv. 2015, 5, 5406-5414. [CrossRef]

95. Faridbod, F.; Norouzi, P.; Dinarvand, R.; Ganjali, M.R. Developments in the field of conducting and non-conducting polymer based potentiometric membrane sensors for ions over the past decade. Sensors 2008, 8, 2331-2412. [CrossRef]

96. Geise, R.J.; Adams, J.M.; Barone, N.J.; Yacynych, A.M. Electropolymerized films to prevent interferences and electrode fouling in biosensors. Biosens. Bioelectron. 1991, 6, 151-160. [CrossRef]

97. Oh, W.H.; Kwon, O.S.; Jang, J. Conducting polymer nanomaterials for biomedical applications: Cellular interfacing and biosensing. Polym. Rev. 2013, 53, 407-442. [CrossRef]

98. Malhotra, B.D.; Chaubey, A.; Singh, S.P. Prospects of conducting polymers in biosensors. Anal. Chim. Acta 2006, 578, 59-74. [CrossRef] 
99. Tully, E.; Higson, S.P.; Kennedy, R.O. The development of a 'labeless' immunosensor for the detection of Listeria monocytogenes cell surface protein, internalin B. Biosens. Bioelectron. 2008, 23, 906-912. [CrossRef] [PubMed]

100. Muhammad-Tahir, Z.; Alocilja, E.C. Fabrication of a disposable biosensor for Escherichia coli O157:H7 detection. IEEE Sens. J. 2003, 3, 345-351. [CrossRef]

101. Muhammad-Tahir, Z.; Alocilja, E.C. A disposable biosensor for pathogen detection in fresh produce samples. Biosyst. Eng. 2004, 88, 145-151. [CrossRef]

102. Sheikhzadeh, E.; Chamsaz, M.; Turner, A.P.F.; Jager, E.W.H.; Beni, V. Label-free impedimetric biosensor for Salmonella typhimurium detection based on poly [pyrrole-co-3-carboxyl-pyrrole] copolymer supported aptamer. Biosens. Bioelectron. 2016, 80, 194-200. [CrossRef]

103. Nordin, N.; Yusof, N.A.; Abdullah, J.; Radu, S.; Hushiarian, R. A simple, portable, electrochemical biosensor to screen shellfish for Vibrio parahaemolyticus. AMB Express 2017, 7, 41. [CrossRef]

104. Nordin, N.; Yusof, N.A.; Radu, S.; Hushiarian, R. Development of an electrochemical DNA biosensor to detect a foodborne pathogen. J. Vis. Exp. 2018, 136, e56585. [CrossRef]

105. Suaifan, G.A.R.Y.; Alhogail, S.; Zourob, M. Rapid and low-cost biosensor for the detection of Staphylococcus aureus. Biosens. Bioelectron. 2017, 90, 230-237. [CrossRef]

106. Viswanathan, S.; Rani, C.; Ho, J.A. Electrochemical immunosensor for multiplexed detection of food-borne pathogens using nanocrystal bioconjugates and MWCNT screen-printed electrode. Talanta 2012, 94, 315-319. [CrossRef]

107. Dong, J.; Zhao, H.; Xu, M.; Ma, Q.; Ai, S. A label-free electrochemical impedance immunosensor based on AuNPs/PAMAM-MWCNT-Chi nanocomposite modified glassy carbon electrode for detection of Salmonella typhimurium in milk. Food Chem. 2013, 141, 1980-1986. [CrossRef]

108. Byeon, H.M.; Vodyanoy, V.J.; Oh, J.H.; Kwon, J.H.; Parka, M.K. Lytic phage-based magnetoelastic biosensors for on-site detection of methicillin-resistant Staphylococcus aureus on spinach leaves. J. Electrochem. Soc. 2015, 162, B230-B234. [CrossRef]

109. Minett, A.I.; Barisci, J.N.; Wallace, G.G. Coupling conducting polymers and mediated electrochemical responses for the detection of Listeria. Anal. Chim. Acta 2003, 475, 37-45. [CrossRef]

110. Sun, Y.; Duan, N.; Ma, P.; Liang, Y.; Zhu, X.; Wang, Z. Colorimetric aptasensor based on truncated aptamer and trivalent DNAzyme for Vibrio parahemolyticus determination. J. Agric. Food Chem. 2019, 67, 2313-2320. [CrossRef]

111. Chen, R.; Huang, X.; Li, J.; Shan, S.; Lai, W.; Xiong, Y. A novel fluorescence immunoassay for the sensitive detection of Escherichia coli O157:H7 in milk based on catalase-mediated fluorescence quenching of CdTe quantum dots. Anal. Chim. Acta 2016, 947, 50-57. [CrossRef] [PubMed]

112. Fang, Z.; Wu, W.; Lu, X.; Zeng, L. Lateral flow biosensor for DNA extraction-free detection of Salmonella based on aptamer mediated strand displacement amplification. Biosens. Bioelectron. 2014, 56, 192-197. [CrossRef] [PubMed]

113. Ravindranath, S.P.; Mauer, L.J.; Deb-Roy, C.; Irudayaraj, J. Biofunctionalized magnetic nanoparticle integrated mid-infrared pathogen sensor for food matrixes. Anal. Chem. 2009, 81, 2840-2846. [CrossRef]

114. Wu, W.; Zhao, S.; Mao, Y.; Fang, Z.; Lu, X.; Zeng, L. A sensitive lateral flow biosensor for Escherichia coli O157:H7 detection based on aptamer mediated strand displacement amplification. Anal. Chim. Acta 2014, 861, 62-68. [CrossRef]

115. Houhoula, D.P.; Charvalos, E.; Konteles, S.; Koussissis, S.; Lougovois, V.; Papaparaskevas, J. A simple gold nanoprobe assay for the identification of Staphylococcus aureus, Listeria monocytogenes and Salmonella enteritidis in food specimens. J. Food Res. 2017, 6, 134-139. [CrossRef]

116. Chinnappan, R.; AlAmer, S.; Eissa, S.; Rahamn, A.A.; Salah, K.M.A.; Zourob, M. Fluorometricgrapheneoxide-baseddetection of Salmonellaenteritis using a truncatedDNAaptamer. Mikrochim. Acta 2017, 185, 61. [CrossRef]

117. Khang, J.; Kim, D.; Chung, K.W.; Lee, J.H. Chemiluminescent aptasensor capable of rapidly quantifying Escherichia coli O157:H7. Talanta 2016, 147, 177-183. [CrossRef]

118. Mak, A.C.; Osterfeld, S.J.; Yu, H.; Wang, S.X.; Davis, R.W.; Jejelowo, O.A.; Pourmand, N. Sensitive giant magnetoresistive-based immunoassay for multiplex mycotoxin detection. Biosens. Bioelectron. 2010, 25, 1635-1639. [CrossRef] 
119. Mollasalehi, H.; Yazdanparast, R. An improved non-crosslinking gold nanoprobe-NASBA based on $16 \mathrm{~S}$ rRNA for rapid discriminative bio-sensing of major salmonellosis pathogens. Biosens. Bioelectron. 2013, 47, 231-236. [CrossRef] [PubMed]

120. Oaew, S.; Charlermroj, R.; Pattarakankul, T.; Karoonuthaisiri, N. Gold nanoparticles/horseradish peroxidase encapsulated polyelectrolyte nanocapsule for signal amplification in Listeria monocytogenes detection. Biosens. Bioelectron. 2012, 34, 238-243. [CrossRef] [PubMed]

121. Rusinek, R.; Gancarz, M.; Krekora, M.; Nawrocka, A. A Novel method for generation of a fingerprint using electronic nose on the example of Rapeseed spoilage. J. Food Sci. 2019, 84, 51-58. [CrossRef] [PubMed]

122. Rusinek, R.; Gancarz, M.; Nawrocka, A. Application of an electronic nose with novel method for generation of smellprints for testing the suitability for consumption of wheat bread during 4-day storage. LWT Food Sci. Technol. 2020, 117, 108665. [CrossRef]

123. Gupta, S.; Kaushal, A.; Kumar, A.; Kumar, D. Ultrasensitive transglutaminase based nanosensor for early detection of celiac disease in human. Int. J. Biol. Macromol. 2017, 5, 905-911. [CrossRef] [PubMed]

124. Saini, K.; Kaushal, A.; Gupta, S.; Kumar, D. Rapid detection of Salmonella enterica in raw milk samples using Stn gene-based biosensor. 3 Biotech 2019, 9, 425. [CrossRef]

125. Saini, K.; Kaushal, A.; Gupta, S.; Kumar, D. Multiplexed Stn and PlcA based specific genetic marker for early detection of Salmonella enterica and Listeria monocytogenes in milk samples. Ann. Univ. Dunarea Jos Galati 2019, 43, 9-20. [CrossRef]

(C) 2020 by the authors. Licensee MDPI, Basel, Switzerland. This article is an open access article distributed under the terms and conditions of the Creative Commons Attribution (CC BY) license (http://creativecommons.org/licenses/by/4.0/). 